Vol. 24, No. 1, Januari 2021, hlm. 47-58

p-ISSN: 1410-9344; e-ISSN: 2549-5631

\title{
Implementasi Hasil Road Safety Audit (RSA) di Ruas Jalan Mayjen Sungkono, Blater, Purbalingga, Jawa Tengah
}

\author{
${ }^{1}$ Gito Sugiyanto, ${ }^{1}$ Suryo Bagus Pratama, ${ }^{2}$ Ari Fadli, ${ }^{3}$ Mina Yumei Santi \\ ${ }^{1}$ Program Studi Teknik Sipil, Fakultas Teknik, Universitas Jenderal Soedirman Purwokerto \\ ${ }^{2}$ Program Studi Teknik Elektro, Fakultas Teknik, Universitas Jenderal Soedirman Purwokerto \\ ${ }^{3}$ Politeknik Kesehatan Kementerian Kesehatan Yogyakarta dan Pusat Unggulan Inovasi (PUI) Teknologi Terapan \\ bidang Kesehatan Masyarakat, Politeknik Kesehatan Kementerian Kesehatan \\ e-mail: ${ }^{1}$ gito.sugiyanto@unsoed.ac.id, ${ }^{2}$ arifadli@unsoed.ac.id, ${ }^{3}$ minayumeisanti80@gmail.com
}

\section{Article Info}

Submitted: 18 April 2020

Revised: 08 July 2020

Accepted: 28 July 2020

Published: 12 December 2020

Keywords : Speed limit, black spot, speeding, road safety audit.

\begin{abstract}
Vulnerable road users are pedestrians, un-motorized users, children, and elderly people. The problem of traffic safety is not only zero accidents, but also broader the creation of safe and comfortable environment for road users. Based on international understanding of traffic safety contained in the Global Road Safety Partnership (GRSP), traffic safety has involved elements of government, business, and civil society with the primary goal of raising awareness about the importance of safety and reducing mortality and injuries due to past accidents cross a sustainable basis, especially in developing and transition countries. To reduce the number of accidents can be done by carrying out and implementing the results of road safety audits, through forgiving roads that are able to minimize the severity of victims, roads that are able to explain intentions without communication (self-explaining road), and roads that are capable of creating compliance without warning (self-regulating road). One of the causes of traffic accidents is human error behavior and speed of vehicles which exceed the speed limits (speeding). One of the strategies to reduce the speeding by way speed restrictions of vehicle. Based on the analysis of the $85^{\text {th }}$ percentile and the probability of a pedestrian fatality rate when hit by a vehicle, the value of the speed limit on school hours at $30 \mathrm{~km} / \mathrm{h}$ and $50 \mathrm{~km} / \mathrm{h}$ for outside the school hours according to the terrain of the existing road with a flat and straight terrain. In Mayjen Sungkono Street (in front of Engineering Faculty Unsoed Blater Campus) along $150 \mathrm{~m}$, the speed limit at $40 \mathrm{~km} / \mathrm{h}$. The results of road safety audit analysis are then implemented in the field by installing traffic signs. Determination of the location of the installation of speed limit signs and crossing road signs is coordinated with Balai Pengelola Sarana Prasarana Perhubungan Wilayah V, Transportation Agency, Central Java Province. There are four traffic signs that are installed on the Mayjen Sungkono Street, Blater which are two speed limit signs of $40 \mathrm{~km} / \mathrm{h}$ and two road crossing instructions.
\end{abstract}


Kata Kunci : Kecepatan maksimum, lokasi rawan kecelakaan lalu lintas, speeding, audit keselamatan jalan.

\begin{abstract}
Abstrak
Pengguna jalan yang paling rentan (vulnerable road users) adalah pejalan kaki, pengguna kendaraan tidak bermotor, anak-anak, dan manusia lanjut usia (manula). Masalah keselamatan lalu lintas tidak hanya terbatas bahwa tidak adanya kecelakaan, namun lebih luas yaitu terciptanya lingkungan yang aman dan nyaman bagi para pengguna jalan. Berdasarkan kesepahaman internasional mengenai keselamatan lalu lintas yang tertuang dalam Global Road Safety Partnership (GRSP), keselamatan lalu lintas telah melibatkan elemenelemen pemerintah, bisnis, dan masyarakat sipil dengan tujuan utama untuk meningkatkan kesadaran tentang pentingnya keselamatan dan menurunkan angka kematian serta luka-luka akibat kecelakaan lalu lintas secara berkesinambungan terutama pada negara-negara berkembang dan transisi. Untuk menekan angka kecelakaan lalu lintas dapat dilakukan dengan melakukan dan mengimplementasikan hasil audit keselamatan jalan, melalui jalan yang pemaaf yang mampu meminimalisir keparahan korban apabila terjadi tabrakan (forgiving road), jalan yang mampu menjelaskan maksud tanpa komunikasi (self-explaining road), dan jalan yang mampu menciptakan kepatuhan tanpa peringatan (self-regulating road). Salah satu faktor penyebab kecelakaan lalu lintas adalah perilaku kelalaian manusia (human error) dan tingginya kecepatan kendaraan yang melampaui batas kecepatan yang ditetapkan (speeding). Strategi yang dapat diterapkan dalam rangka mengurangi pelanggaran batas kecepatan maksimum (speeding) yaitu dengan cara membatasi kecepatan maksimum kendaraan. Berdasar hasil analisis dari percentile $85^{\text {th }}$ dan probabilitas tingkat fatalitas pejalan kaki saat ditabrak kendaraan, diperoleh nilai batas kecepatan pada jam masuk/pulang sekolah sebesar $30 \mathrm{~km} / \mathrm{jam}$ dan $50 \mathrm{~km} / \mathrm{jam}$ untuk di luar jam sekolah pada medan datar dan lurus. Untuk ruas Jalan Mayor Jenderal Sungkono km 5 di depan Kampus Fakultas Teknik Unsoed Blater sepanjang $150 \mathrm{~m}$ ditetapkan nilai batas kecepatan maksimum sebesar $40 \mathrm{~km} / \mathrm{jam}$. Hasil analisis audit keselamatan jalan selanjutnya diimplementasikan di lapangan dengan memasang rambu lalu lintas. Penentuan titik lokasi pemasangan rambu batas kecepatan maksimum dan rambu petunjuk penyeberangan jalan dikoordinasikan dan melibatkan pihak Balai Pengelola Sarana Prasarana Perhubungan Wilayah V, Dinas Perhubungan, Provinsi Jawa Tengah. Terdapat empat buah rambu lalu lintas yang dipasang di ruas Jalan Mayor Jenderal Sungkono km 5, Blater yaitu dua buah rambu batas kecepatan maksimum $40 \mathrm{~km} / \mathrm{jam}$ dan dua buah rambu petunjuk penyeberangan jalan.
\end{abstract}

\section{PENDAHULUAN}

Kebijakan, perencanaan, dan programprogram keselamatan jalan di negara maju disusun berdasarkan sistem pangkalan data yang telah terbangun. Akan tetapi di Indonesia, hal ini belum dapat dilakukan sepenuhnya karena adanya berbagai hal seperti tidak tersedianya data secara lengkap dan data yang tersedia hanya bersifat umum sehingga kurang memberikan informasi yang spesifik. Kalaupun data tersedia tetapi tidak dikumpulkan secara rutin atau tidak dikumpulkan pada lokus yang sama dan sebagainya. Khusus untuk sosialisasi keselamatan jalan, bila sistem pangkalan data 
belum terwujud dengan sempurna, maka datadata perilaku (attitude)-kebiasaan (behavior)pengetahuan (knowledge) dari pengguna jalan dapat dipakai untuk mengukur tingkat keberhasilan/kegagalan/peningkatan yang dicapai dari suatu program keselamatan. Keuntungan pemakaian data perilakukebiasaan-pengetahuan pengguna jalan adalah dapat langsung diidentifikasi perilaku yang menyimpang dari suatu penerapan program keselamatan tertentu, sehingga suatu program tertentu dapat segera diperbaiki atau dijustifikasi sesuai dengan keperluan dan kondisi target kelompok pengguna jalan.

Angka kecelakaan dan jumlah korban kecelakaan lalu lintas di Indonesia masih tinggi. Mengacu pada data Korlantas Polri, kecelakaan lalu lintas pada tahun 2018 mencapai 107.968 kasus kecelakaan dengan jumlah korban meninggal dunia 29.083 orang, korban luka berat 13.258 orang, korban luka ringan 129.095 , dan kerusakan harta benda (property damage only) mencapai $\mathrm{Rp} 212.148 .000 .000,00$ (Korps Lalu Lintas, 2019). Hal yang sama juga terjadi di Kabupaten Purbalingga, yang mana jumlah kecelakaan lalu lintas mengalami peningkatan dari tahun 2010 s.d 2017, seperti ditunjukkan pada Tabel 1. Hasil analisis karakteristik kecelakaan lalu lintas di Kabupaten Purbalingga meliputi jumlah kejadian kecelakaan, tingkat fatalitas korban kecelakaan, usia korban, jenis kendaraan yang terlibat kecelakaan. Data kecelakaan lalu lintas yang dianalisis bersumber dari Kepolisian Resor Purbalingga selama periode delapan tahun terakhir yaitu tahun 2010 s.d 2017. Selama periode tahun 2010 s.d 2017 terjadi sebanyak 3447 kejadian kecelakaan lalu lintas dengan jumlah kejadian tertinggi terjadi pada tahun 2016 sebanyak 574 kasus, diikuti tahun 2017 sebanyak 559 kasus kecelakaan, diikuti tahun 2015 sebanyak 548 kasus kecelakaan dan pada tahun 2012 sebanyak 475 kejadian kecelakaan (Polres Purbalingga, 2018). Karakteristik kecelakaan lalu lintas berdasarkan jumlah kejadian kecelakaan di Kabupaten Purbalingga tahun 2010 s.d 2017 seperti ditunjukkan pada Gambar 1. Jumlah korban kecelakaan lalu lintas di Kabupaten Purbalingga, Provinsi Jawa Tengah dari tahun 2010-2017 ditunjukkan pada Gambar 2.

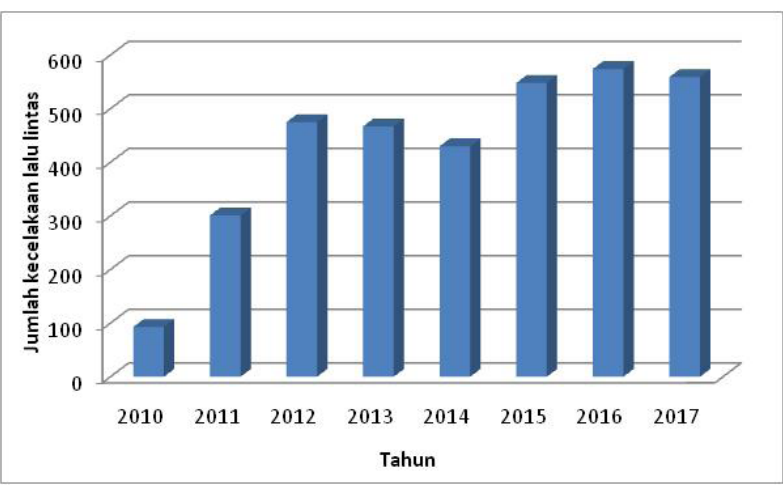

Gambar 1. Jumlah kejadian kecelakaan lalu lintas di Kabupaten Purbalingga tahun 2010 s.d 2017

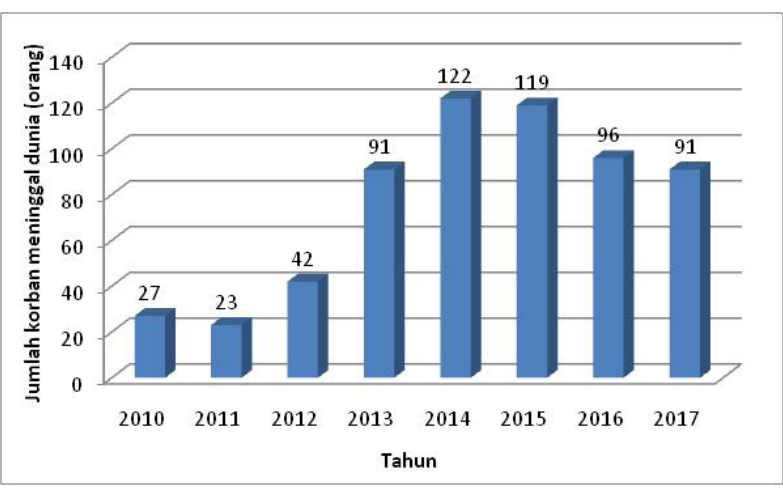

Gambar 2. Jumlah korban meninggal dunia akibat kecelakaan lalu lintas tahun 2010 s.d 2017

Tabel 1. Data jumlah dan korban kecelakaan lalu lintas di Kabupaten Purbalingga 2010-2017

\begin{tabular}{lcccccccc}
\hline Kecelakaan lalu lintas & 2010 & 2011 & 2012 & 2013 & 2014 & 2015 & 2016 & 2017 \\
\hline Jumlah kecelakaan & 93 & 301 & 475 & 467 & 430 & 548 & 574 & 559 \\
\hline Meninggal dunia & 27 & 23 & 42 & 91 & 122 & 119 & 96 & 91 \\
\hline Luka berat & 4 & 18 & 3 & 1 & 0 & 1 & 1 & 4 \\
\hline Luka ringan & 169 & 573 & 857 & 751 & 602 & 800 & 820 & 817 \\
\hline Kerugian harta benda (Rp) & $\begin{array}{c}102,9 \\
\text { juta }\end{array}$ & $\begin{array}{c}289,6 \\
\text { juta }\end{array}$ & $\begin{array}{c}423,2 \\
\text { juta }\end{array}$ & $\begin{array}{c}363,1 \\
\text { juta }\end{array}$ & $\begin{array}{c}453,8 \\
\text { juta }\end{array}$ & $\begin{array}{c}432,5 \\
\text { juta }\end{array}$ & $\begin{array}{c}307,8 \\
\text { juta }\end{array}$ & $\begin{array}{c}307,25 \\
\text { juta }\end{array}$ \\
\hline
\end{tabular}


Angka kecelakaan lalu lintas semakin meningkat seiring dengan bertambahnya jumlah kendaraan khususnya sepeda motor dan mengendarai kendaraan melebihi batas kecepatan maksimum yang diijinkan atau speeding (Sugiyanto et al., 2017; Sugiyanto \& Malkhamah, 2018; Sugiyanto et al., 2019a). Jumlah kendaraan bermotor pada tahun 2018 menurut jenisnya adalah mobil penumpang 17.072.358 unit, mobil beban 6.888.693 unit, bus 2.039.037 unit, dan sepeda motor 114.785.638 unit (Kementerian Perhubungan, 2019). Kecelakaan lalu lintas menjadi penyebab kematian di urutan ke-8 pada tahun 1990 dan naik menjadi urutan ke-6 pada tahun 2017 (The Institute for Health Metrics and Evaluation, 2018). Tiga faktor penyebab kecelakaan lalu lintas yaitu manusia, kendaraan, dan lingkungan (Sugiyanto \& Santi, 2015). Penyebab kecelakaan yang paling banyak di Indonesia disebabkan oleh faktor manusia (91\%), diikuti faktor kendaraan (5\%), faktor jalan (3\%), dan faktor lingkungan sekitar 1\% (Direktorat Keselamatan Transportasi Darat, 2006). Menurut Treat et al. (1977) faktor terjadinya kecelakaan tidak hanya berdasarkan faktor tunggal, melainkan terjadi akibat dua faktor atau lebih. Terdapat tiga faktor penyebab kecelakaan lalu lintas yaitu faktor kesalahan manusia atau human errors sebesar 95,4\%, faktor kendaraan sebesar 14,8\%, dan faktor jalan dan lingkungan sebesar 44,2\%. Interaksi antara faktor kesalahan manusia dan infrastruktur jalan menyebabkan kecelakaan lalu lintas sebesar $34,8 \%$; interaksi antara faktor kendaraan dan kesalahan manusia sebesar 6,4\% dan interaksi antara faktor kendaraan dan jalan/lingkungan sebesar $0,4 \%$, dan interkasi ketiganya sebesar 6,4\%. Distribusi faktor penyebab kecelakaan lalu lintas selengkapnya seperti yang ditunjukkan pada Gambar 3.

Untuk faktor penyebab kecelakaan lalu lintas yang berasal dari sektor infrastruktur jalan upaya untuk meminimalkan terjadinya defisiensi infrastruktur jalan, dapat dilakukan dengan tiga aspek yaitu jalan yang pemaaf (forgiving road) yang mampu meminimalisir keparahan korban apabila tabrakan. Aspek yang kedua yaitu jalan yang mampu menjelaskan maksud tanpa komunikasi (self-explaining road), dan aspek yang ketiga yaitu jalan mampu menciptakan kepatuhan tanpa peringatan (self-regulating

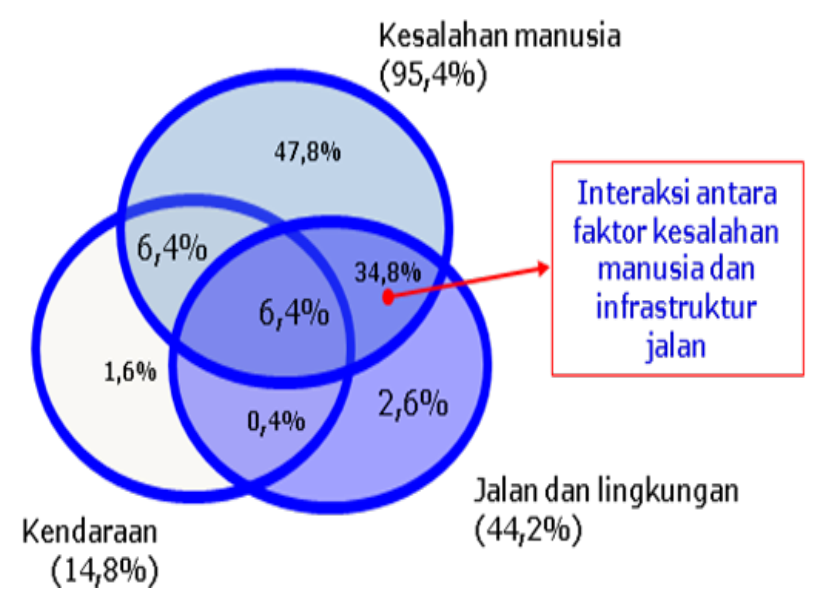

Sumber: Treat et al., 1977.

Gambar 3. Distribusi faktor penyebab kecelakaan lalu lintas.

road) (Direktorat Jenderal Bina Marga, 2006). Kecepatan merupakan salah satu komponen yang berkontribusi terhadap kecelakaan lalu lintas (Hughes et al., 2015; Wang et al., 2018; Sugiyanto et al., 2019b). Oleh karena itu, model keselamatan jalan difokuskan terutama pada faktor risiko (Schepers, 2014).

Salah satu upaya yang dilakukan untuk mengatasi tingginya tingkat kecelakaan lalu lintas di Kabupaten Purbalingga adalah dengan cara membangun sistem informasi geografis berbasis web sebagai portal informasi untuk masyarakat mengetahui lokasi rawan kecelakaan di Kabupaten Purbalingga (Sugiyanto \& Fadli, 2017; Fadli etal., 2020). Upaya untuk mengurangi kecelakaan lalu lintas yaitu dengan cara melakukan penentuan dan penanganan lokasi rawan kecelakaan lalu lintas. "Lokasi rawan kecelakaan lalu lintas didefinisikan sebagai suatu lokasi di mana angka kecelakaan tinggi dengan kejadian kecelakaan berulang dalam suatu ruang dan rentang waktu yang relatif sama yang diakibatkan oleh suatu penyebab tertentu" (Pusat Litbang Prasarana Transportasi, 2005).

World Health Organization (WHO) mencatat hampir 1,2 juta orang di seluruh dunia setiap tahun meninggal dunia akibat kecelakaan di jalan. Jutaan lagi mengalami cidera dan sebagian lagi mengalami cacat seumur hidup (Direktorat Jenderal Perhubungan Darat, 2004). Kerugian akibat kecelakaan lalu lintas pada tahun 2002 mencapai Rp 41,4 triliun (Direktorat Keselamatan Transportasi Darat, 2006). Menurut World Health Organization, kecelakaan lalu 
lintas di Indonesia dinilai menjadi pembunuh terbesar ketiga, di bawah penyakit jantung koroner dan Tuberculosis atau TBC. Global Status Report on Road Safety 2013 menempatkan Indonesia sebagai negara urutan kelima tertinggi angka kecelakaan lalu lintas di dunia (Gresnews, 2014). Di Indonesia, sebagian besar kecelakaan lalu lintas melibatkan pengendara sepeda motor. Berdasarkan kelompok usia korban, rentang usia 15-19 tahun mendominasi korban yang meninggal dunia, diikuti rentang usia 20-24 tahun, seperti ditunjukkan pada Gambar 2 (Korlantas, 2019). Penerapan biaya kemacetan atau congestion pricing di kawasan central business district (Sugiyanto, 2008; Sugiyanto, 2016), penerapan biaya kemacetan bagi pengguna mobil pribadi (Sugiyanto, 2018), identifikasi lokasi rawan kecelakaan lalu lintas (Sugiyanto et al., 2017) adalah berbagai metode yang telah dicoba untuk mengurangi biaya transportasi di Indonesia.

Penelitian terkait keselamatan lalu lintas di Benua Eropa, menunjukkan bahwa kecelakaan cenderung terkonsentrasi pada ruas jalan tertentu. Beberapa parameter yang digunakan untuk menganalisis penyebab kecelakaan lalu lintas di jalan raya adalah geometrik jalan, perilaku mengemudi, kondisi cuaca, dan batas kecepatan maksimum kendaraan (Majid \& Mehrzad, 2013). Hal itu menunjukkan bahwa selain faktor kesalahan pengemudi (human error), karakteristik jalan merupakan salah satu faktor penting dalam terjadinya kecelakaan lalu lintas di jalan raya.

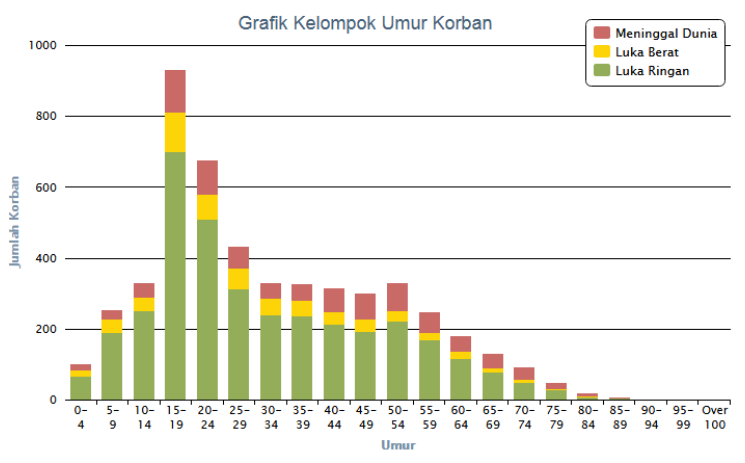

Sumber: http://korlantas.polri.go.id/korlantas/ statistik-2/, 2019.

Gambar 4. Distribusi korban kecelakaan lalu lintas berdasarkan kelompok umur korban.

\section{METODE}

Penentuan nilai batas kecepatan maksimum kendaraan menggunakan pendekatan $85^{\text {th }}$ percentile. Kecepatan $85^{\text {th }}$ persentil adalah kecepatan lalu lintas di mana $85 \%$ dari pengemudi mengemudikan kendaraannya di jalan tanpa dipengaruhi oleh kecepatan lalu lintas yang lebih rendah atau cuaca yang buruk. Dengan kata lain, kecepatan $85^{\text {th }}$ persentil merupakan kecepatan yang digunakan oleh $85^{\text {th }}$ persentil pengemudi yang diharapkan dapat mewakili kecepatan yang sering digunakan pengemudi di lapangan (Sendow, 2004).

Tahapan kegiatan yang dilakukan pada kegiatan pengabdian kepada masyarakat skim program kemitraan masyarakat tahun 2019 adalah sebagai berikut:

a. Melakukan survei kondisi geometrik jalan, hambatan samping, rambu lalu lintas, dan marka jalan di ruas Jalan Mayjen Sungkono, Blater, Purbalingga. Data tersebut digunakan untuk melakukan analisis audit keselamatan jalan.

b. Melakukan survei kecepatan kendaraan di ruas Jalan Mayjen Sungkono, Blater, Purbalingga. Kecepatan kendaraan dikelompokkan menjadi 7 (tujuh) golongan kendaraan yaitu sepeda motor, mobil penumpang, pick up dan angkutan kota, truk kecil, truk besar, bus kecil, dan bus besar.

c. Merekap data kecepatan kendaraan dan menganalisis kecepatan dengan menggunakan persentil $85^{\text {th }}$, sehingga diperoleh nilai kecepatan maksimum serta analisis statistik untuk mendapatkan nilai mean, modus, median, variance, dan standar deviasi kecepatan.

d. Membandingkan nilai kecepatan pada persentil $85^{\text {th }}$ dengan batas kecepatan maksimum kendaraan yang ada di dalam Peraturan Menteri Perhubungan Republik Indonesia PM Nomor 111 tahun 2015 tentang tentang Tata Cara Penetapan Batas Kecepatan.

e. Membandingkan hasil nilai langkah ketiga (kecepatan kendaraan di lapangan) dengan grafik tingkat fatalitas mengacu pada hasil studi Global Road Safety Partnership (GRSP) Tahun 2008 (ditunjukkan pada Gambar 6).

f. Mengusulkan dan menetapkan nilai batas 
kecepatan maksimum kendaraan untuk ruas Jalan Mayjen Sungkono, Blater, Purbalingga (mengacu pada hasil langkah ke-5). Nilai batas kecepatan maksimum yang diusulkan dikoordinasikan dengan pihak Balai Pengelola Sarana Prasarana Perhubungan Wilayah $\mathrm{V}$ untuk mendapatkan persetujuan.

g. Memesan rambu batas kecepatan maksimum kendaraan dan rambu petunjuk penyeberangan jalan ke PT Qumicon Indonesia di Yogyakarta.

h. Berkoordinasi dengan pihak Balai Pengelola Sarana Prasarana Perhubungan Wilayah V, Dinas Perhubungan, Provinsi Jawa Tengah untuk menentukan titik lokasi pemasangan rambu lalu lintas. Pada tahap ini melibatkan Dinas Perhubungan karena ruas Jalan Mayjen Sungkono merupakan ruas jalan provinsi.

i. Memasang rambu lalu lintas batas kecepatan maksimum kendaraan dan rambu lalu lintas petunjuk penyeberangan jalan di lapangan. Pada tahap pemasangan rambu lalu lintas di lapangan melibatkan pihak Dinas Perhubungan, Provinsi Jawa Tengah dan warga Desa Blater.

\section{HASIL DAN PEMBAHASAN}

\section{Lokasi Rawan Kecelakaan Lalu Lintas dan Audit Keselamatan Jalan}

Penentuan lokasi rawan kecelakaan lalu lintas di Kabupaten Purbalingga dengan menggunakan nilai angka ekivalen kecelakaan dan metode upper control limit seperti yang dilakukan oleh Sugiyanto (2017) dan Sugiyanto \& Santi (2017). Nilai faktor probabilitas ( $\Psi$ ) pada perhitungan upper control limits ditentukan oleh probabilitas bahwa tingkat kecelakaan cukup besar sehingga kecelakaan tidak dapat dianggap sebagai kejadian acak (Khisty \& Kent, 2003). Berdasarkan Pedoman Perencanaan Geometrik Jalan Antar Kota (Direktorat Jenderal Bina Marga, 1997), lebar minimum bahu jalan standar $150 \mathrm{~cm}$ dan lebar jalan 6,00 m. Rambu larangan, rambu petunjuk, rambu perintah, dan rambu peringatan mengacu pada standar Peraturan Menteri Perhubungan Republik Indonesia PM Nomor 13 Tahun 2014 tentang Rambu Lalu Lintas (Kementerian Perhubungan Republik Indonesia,
2014). Marka jalan mengacu pada standar dari Kementerian Perhubungan yaitu PM Nomor 67 Tahun 2018 tentang Perubahan atas Peraturan Menteri Perhubungan Nomor PM 34 Tahun 2014 tentang Marka Jalan (Kementerian Perhubungan Republik Indonesia, 2018). Menurut Peraturan Menteri Perhubungan Republik Indonesia Nomor 111 Tahun 2015 tentang Tata Cara Penetapan Batas Kecepatan, batas kecepatan maksimum disesuaikan dengan kelas jalan dan jenis kendaraan (Kemenhub, 2015). Penetapan batas kecepatan harus memperhatikan karakteristik lalu lintas, kondisi jalan, dan tipe tata guna lahan (pusat kegiatan bisnis, industri, permukiman, dan sekolah).

Hasil audit keselamatan jalan di ruas Jalan Mayjen Sungkono, Blater, Purbalingga yang harus diperbaiki yaitu aspek geometrik jalan berupa beda elevasi jalan dengan bahu dan aspek harmonisasi fasilitas perlengkapan jalan. Implementasi dari hasil audit keselamatan jalan yang dilakukan melalui skim program kemitraan masyarakat yaitu dengan menentukan nilai batas kecepatan pada saat jam masuk/pulang sekolah sebesar $30 \mathrm{~km} / \mathrm{jam}$, melakukan pengurugan bahu jalan sehingga elevasi atau ketinggian antara bahu jalan dengan badan jalan sama tinggi dan memasang empat buah rambu lalu lintas yang terdiri dua buah rambu batas kecepatan maksimum kendaraan $40 \mathrm{~km} / \mathrm{jam}$ di kawasan Kampus Fakultas Teknik Unsoed Blater dan dua buah rambu lalu lintas petunjuk penyeberangan jalan.

Kondisi Geometrik Jalan, Rambu Lalu Lintas, dan Marka Jalan di Ruas Jalan Mayjen Sungkono, Blater, Purbalingga

Kondisi geometrik jalan, rambu lalu lintas, dan marka jalan di ruas Jalan Mayjen Sungkono, Blater, Purbalingga adalah sebagai berikut:

1. Ruas Jalan Mayjen Sungkono berdasarkan status kewenangan jalan masuk ke jalan provinsi.

2. Ruas Jalan Mayjen Sungkono merupakan jalan arteri sekunder antar kota dengan tipe jalan empat lajur 2 arah tanpa median (4/2 TT) dan total lebar jalan $11 \mathrm{~m}$.

3. Terdapat bahu jalan pada sisi ruas Purwokerto-Purbalingga sebesar $1,75 \mathrm{~m}$ dan pada sisi ruas Purbalingga-Purwokerto 
sebesar 1,50 m.

4. Marka jalan dengan kondisi yang masih baik dan terdapat marka zebra cross di depan Kampus Fakultas Teknik UNSOED Purwokerto.

5. Tidak terdapat rambu batas kecepatan maksimum kendaraan, rambu petunjuk penyeberang jalan, dan rambu Zona Selamat Sekolah (ZoSS).

6. Tipe medan jalan adalah jalan lurus dan datar.

\section{Survei Kecepatan Kendaraan}

Setelah mendapatkan data geometrik jalan, rambu lalu lintas, dan marka jalan maka langkah selanjutnya adalah melakukan survei kecepatan kendaraan. Alat yang digunakan untuk mengambil data kecepatan kendaraan adalah adalah speed gun Bushnell. Jenis kendaraan yang ada di lapangan dikelompokkan menjadi 7 (tujuh) golongan yaitu sepeda motor, mobil penumpang, pick up dan angkutan kota, truk kecil, truk besar, bus kecil, dan bus besar. Dokumentasi pengambilan data kecepatan kendaraan di lapangan seperti ditunjukkan pada Gambar 5 berikut ini.
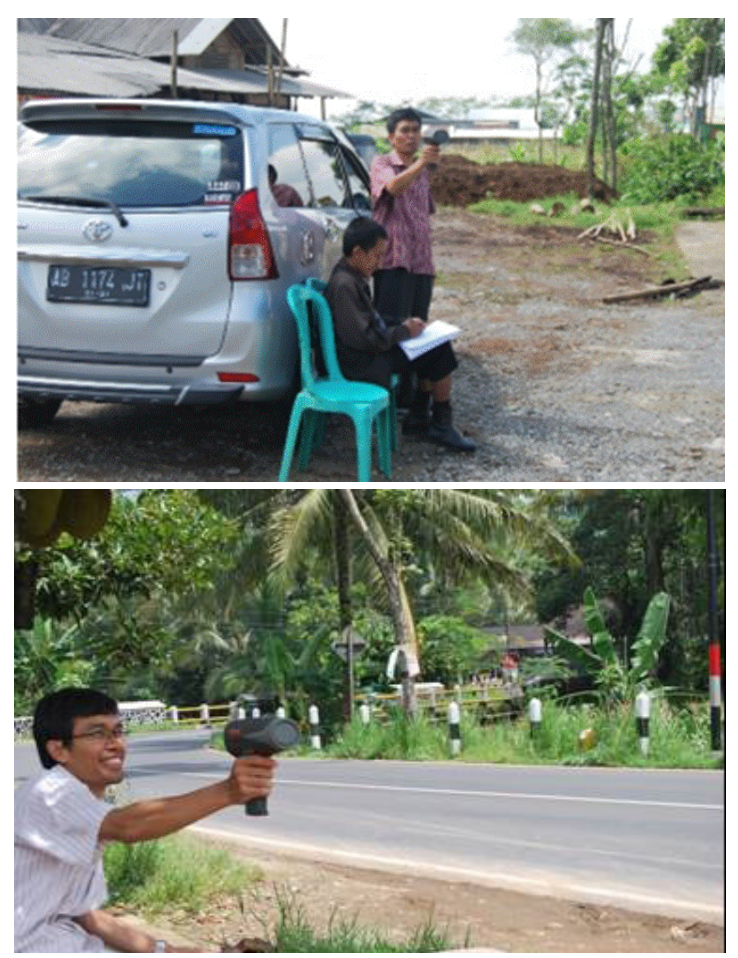

Gambar 5. Survei kecepatan kendaraan dengan menggunakan alat speed gun Bushnell.

Analisis Statistik Kecepatan Kendaraan
Berdasarkan data hasil survei kecepatan kendaraan dengan menggunakan alat speed gun Bushnell, maka langkah selanjutnya adalah melakukan analisis statistik data kecepatan kendaraan. Hasil analisis statistik kecepatan kendaraan berupa nilai mean, modus, median, variance, standar deviasi, kecepatan maksimum, dan kecepatan minimum, nilai percentile $85^{\text {th }}$, percentile $50^{\text {th }}$, dan percentile $15^{\text {th }}$. Analisis statistik kecepatan kendaraan ditunjukkan berdasar jenis kendaraan dan untuk total gabungan semua jenis kendaraan. Hasil analisis statistik kecepatan kendaraan selengkapnya seperti ditunjukkan pada Tabel 2 .

Berdasarkan Tabel 2 dapat diketahui bahwa dari 7 (tujuh) jenis kendaraan yang terdiri dari sepeda motor, mobil penumpang, pick up dan angkutan kota, truk kecil, truk besar, bus kecil, dan bus besar dengan total 425 kendaraan yang disurvei, nilai percentile $85^{\text {th }}$ untuk semua jenis kendaraan di Jalan Mayjen Sungkono diperoleh sebesar $42 \mathrm{~km} / \mathrm{jam}$ dan nilai percentile $15^{\text {th }}$ sebesar $26 \mathrm{~km} / \mathrm{jam}$. Nilai rata-rata kecepatan kendaraan sebesar $34 \mathrm{~km} / \mathrm{jam}$. Nilai kecepatan percentile $85^{\text {th }}$ untuk setiap jenis kendaraan sebagai berikut: sepeda motor $43 \mathrm{~km} / \mathrm{jam}$, mobil penumpang $40 \mathrm{~km} / \mathrm{jam}$, pick up dan angkutan kota $37 \mathrm{~km} / \mathrm{jam}$, truk kecil $33 \mathrm{~km} / \mathrm{jam}$, truk besar $29 \mathrm{~km} / \mathrm{jam}$, bus kecil $42 \mathrm{~km} / \mathrm{jam}$, dan bus besar $39 \mathrm{~km} / \mathrm{jam}$. Kecepatan kendaraan yang paling tinggi sebesar $67 \mathrm{~km} / \mathrm{jam}$ dari jenis kendaraan sepeda motor. Kecepatan terendah diperoleh sebesar $18 \mathrm{~km} / \mathrm{jam}$ juga untuk jenis kendaraan sepeda motor. Nilai kecepatan pada percentile $85^{\text {th }}$ untuk 425 kendaraan sebesar $42 \mathrm{~km} / \mathrm{jam}$. Berdasarkan hasil analisis statistik kecepatan kendaraan, selanjutnya dilakukan rekapitulasi terhadap nilai kecepatan percentile $85^{\text {th }}$ untuk dijadikan nilai kecepatan kendaraan existing di lapangan yang akan dibandingkan dengan nilai batas kecepatan mengacu pada Peraturan Menteri Perhubungan Republik Indonesia Nomor 111 tahun 2015 tentang Tata Cara Penetapan Batas Kecepatan.

\section{Analisis Tingkat Fatalitas}

Analisis tingkat fatalitas diperlukan untuk mengetahui tingkat risiko yang dialami oleh korban jika terlibat kecelakaan lalu lintas (Pratama, 2019). Semakin tinggi kecepatan kendaraan, maka semakin tinggi pula probabilitas 
Sugiyanto, dkk - Implementasi Hasil Road Safety Audit (RSA) ...

Tabel 2. Analisis statistik kecepatan kendaraan di ruas Jalan Mayjen Sungkono, Purbalingga.

\begin{tabular}{|c|c|c|c|c|c|c|c|c|c|}
\hline \multicolumn{2}{|c|}{$\begin{array}{l}\text { Analisis } \\
\text { Statistik }\end{array}$} & $\begin{array}{c}\text { Sepeda } \\
\text { Motor } \\
(\mathrm{km} / \mathrm{jam})\end{array}$ & $\begin{array}{c}\text { Mobil } \\
\text { Penumpang } \\
\text { (km/jam) }\end{array}$ & $\begin{array}{l}\text { Pick up } \\
\text { (km/ } \\
\text { jam) }\end{array}$ & $\begin{array}{c}\text { Truk } \\
\text { Kecil } \\
(\mathrm{km} / \mathrm{jam})\end{array}$ & $\begin{array}{c}\text { Truk } \\
\text { Besar } \\
(\mathrm{km} / \mathrm{jam})\end{array}$ & $\begin{array}{l}\text { Bus Kecil } \\
(\mathrm{km} / \mathrm{jam})\end{array}$ & $\begin{array}{l}\text { Bus Besar } \\
(\mathrm{km} / \mathrm{jam})\end{array}$ & $\begin{array}{l}\text { Total } \\
(\mathrm{km} / \\
\mathrm{jam}) \\
\end{array}$ \\
\hline \multicolumn{2}{|l|}{ Mean } & 35 & 30 & 29 & 29 & 27 & 32 & 34 & 34 \\
\hline \multicolumn{2}{|l|}{ Modus } & 37 & 27 & 24 & 28 & 28 & 26 & 36 & 28 \\
\hline \multicolumn{2}{|l|}{ Median } & 35 & 30 & 29 & 29 & 28 & 31 & 37 & 34 \\
\hline \multicolumn{2}{|l|}{ Variance } & 64 & 46 & 34 & 14 & 5 & 35 & 36 & 62 \\
\hline \multicolumn{2}{|c|}{ Standar deviasi } & 8 & 7 & 6 & 4 & 2 & 6 & 6 & 7 \\
\hline \multicolumn{2}{|c|}{ Kec. maksimum } & 67 & 43 & 38 & 33 & 30 & 43 & 40 & 67 \\
\hline \multicolumn{2}{|c|}{ Kec. minimum } & 18 & 19 & 22 & 20 & 24 & 24 & 25 & 18 \\
\hline \multicolumn{2}{|c|}{ Jumlah data } & 335 & 40 & 10 & 10 & 5 & 20 & 5 & 425 \\
\hline \multirow{3}{*}{ Percentile } & 15 & 27 & 23 & 23 & 25 & 26 & 26 & 29 & 26 \\
\hline & 50 & 35 & 30 & 29 & 29 & 28 & 31 & 37 & 34 \\
\hline & 85 & 43 & 40 & 37 & 33 & 29 & 42 & 39 & 42 \\
\hline
\end{tabular}

tingkat fatalitas yang akan dialami korban. Gambar 6 ditunjukkan probabilitas tingkat fatalitas yang terjadi dan angka persentase yang telah ditetapkan. Mengacu pada grafik hubungan antara kecepatan kendaraan $(\mathrm{km} / \mathrm{jam})$ dan probabilitas pejalan kaki meninggal dunia jika tertabrak kendaraan bermotor maka ditetapkan nilai probabilitas sebesar 10-20\%. Angka persentase tingkat fatalitas ditetapkan sebesar $10-20 \%$, ini digunakan pada saat jam berangkat atau jam pulang sekolah, sedangkan untuk nilai di luar jam tersebut dapat ditentukan lebih besar. Angka ini ditetapkan mengingat batas kecepatan maksimum kendaraan dalam Peraturan Menteri Perhubungan Republik Indonesia Nomor 111 tahun 2015 untuk kawasan sekolah berada pada nilai $30 \mathrm{~km} / \mathrm{jam}$. Jika angka 10-20\% ditarik pada grafik ke arah kurva S maka kecepatan kendaraan berada pada rentang nilai $30-35 \mathrm{~km} / \mathrm{jam}$.

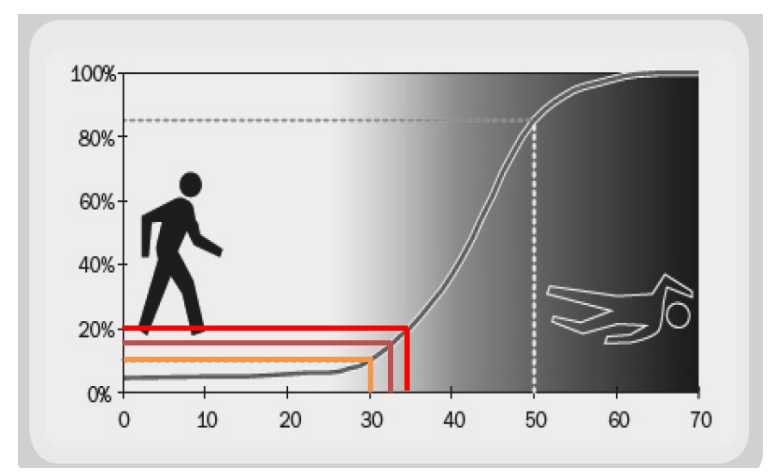

Gambar 6. Probabilitas tingkat fatalitas dengan nilai persentase yang telah ditetapkan.

\section{Penentuan Nilai Batas Kecepatan Maksimum Kendaraan}

Penentuan nilai batas kecepatan maksimum kendaraan harus memperhatikan karakteristik lalu lintas, kondisi jalan, dan tipe tata guna lahan (pusat kegiatan, industri, permukiman, dan sekolah). Berdasarkan rekapitulasi kecepatan percentile $85^{\text {th }}$ pada Tabel 2 , totalsemuakendaraan diperoleh $42 \mathrm{~km} / \mathrm{jam}$ dan juga analisis tingkat fatalitas pada Gambar 6 dengan nilai probabilitas $20 \%$ angka fatalitas maka didapat kecepatan 35 $\mathrm{km} / \mathrm{jam}$. Berdasarkan hasil kedua analisis, nilai kecepatan berada di atas nilai yang ditetapkan dalam Peraturan Menteri Perhubungan Republik Indonesia Nomor 111 tahun 2015 yang mengatur batas kecepatan di kawasan sekolah pada jam masuk/pulang sekolah 30 $\mathrm{km} / \mathrm{jam}$. Maka ditentukan nilai batas kecepatan pada saat jam masuk/pulang sekolah $30 \mathrm{~km} /$ jam untuk semua jenis kendaraan. Penentuan batas kecepatan kendaraan harus dilakukan secara cermat seperti halnya penentuan RPJMDesa (Indrastanti, 2010). Mengingat ruas Jalan Mayjen Sungkono adalah jalan arteri sekunder dan merupakan jalan provinsi maka nilai batas kecepatan di ruas sebelum memasuki kawasan Kampus Fakultas Teknik Universitas Jenderal Soedirman dan Sekolah Dasar Negeri 1 Blater, Purbalingga ditetapkan sebesar 40 km/jam. 


\section{Penentuan Titik Lokasi Pemasangan Rambu Lalu Lintas}

Berdasarkan hasil audit keselamatan jalan dan analisis defisiensi infrastruktur jalan, salah satu upaya untuk meningkatkan keselamatan di ruas Jalan Mayjen Sungkono km 5, Blater, Purbalingga adalah dengan memasang ramburambu lalu lintas terutama rambu batas kecepatan. Penentuan titik lokasi pemasangan rambu lalu lintas di lokasi rawan kecelakaan lalu lintas dilakukan koordinasi dengan Balai Pengelola Sarana Prasarana Perhubungan Wilayah V, Dinas Perhubungan, Provinsi Jawa Tengah. Koordinasi ini dilakukan mengingat bahwa berdasarkan status kewenangan, ruas Jalan Mayjen Sungkono Blater, Purbalingga merupakan jalan provinsi di bawah kewenangan Provinsi Jawa Tengah. Pelibatan pihak Balai Pengelola Sarana Prasarana Perhubungan Wilayah V, Dinas Perhubungan, Provinsi Jawa Tengah juga dilakukan dengan tujuan untuk meng-update informasi koordinat titiktitik lokasi pemasangan rambu lalu lintas di lapangan. Pemasangan rambu lalu lintas dipilih pada titik yang dapat dilihat oleh pengendara dan pengemudi kendaraan dengan jelas, tidak tertutup oleh pohon atau bangunan lain, dipasang di batas bahu jalan, dan memenuhi aspek harmonisasi fasilitas perlengkapan jalan khususnya antara rambu lalu lintas dan marka jalan. Dokumentasi penentuan titik lokasi pemasangan rambu lalu lintas di lapangan seperti ditunjukkan pada Gambar 7 berikut ini.

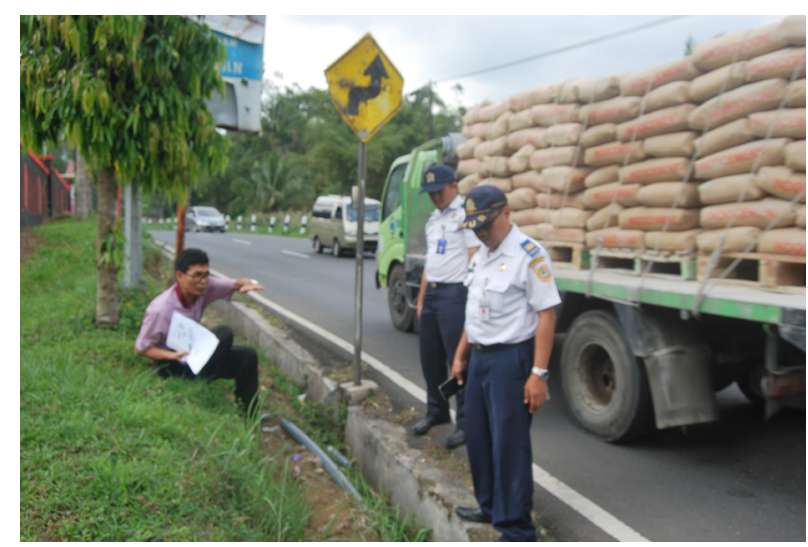

Gambar 7. Koordinasi penentuan titik lokasi pemasangan rambu lalu lintas di lapangan dengan pihak Balai Pengelola Sarana Prasarana Perhubungan, Dinas Perhubungan.

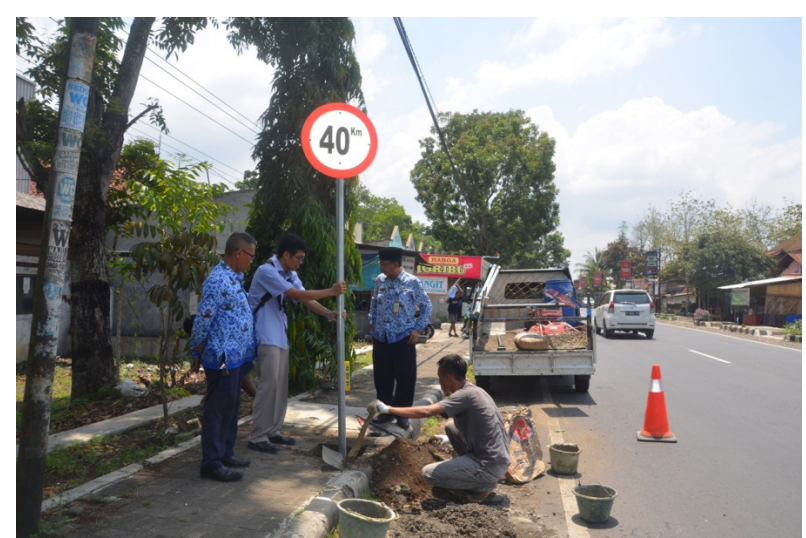

Gambar 8. Pemasangan rambu batas kecepatan maksimum kendaraan $40 \mathrm{~km} / \mathrm{jam}$.

\section{Pemasangan Rambu Batas Kecepatan dan Rambu Petunjuk Penyeberangan Jalan}

Terdapat empat buah rambu lalu lintas yang dipasang di ruas Jalan Mayjen Sungkono, Blater, Purbalingga. Dua buah rambu batas kecepatan maksimum dengan nilai $40 \mathrm{~km} / \mathrm{jam}$ yang dipasang di ruas Jalan Mayjen Sungkono sebelum memasuki kawasan Kampus Fakultas Teknik Unsoed Blater dan SD N 1 Blater di sisi sebelah kiri dan sebelah kanan. Pemasangan rambu lalu lintas di lapangan juga dihadiri oleh Kepala Balai Pengelola Sarana Prasarana Perhubungan Wilayah V, Dinas Perhubungan, Provinsi Jawa Tengah dan staf. Pemasangan rambu lalu lintas melibatkan warga masyarakat. Rambu batas kecepatan maksimum dipasang agak serong sehingga dapat terlihat dengan jelas oleh pengemudi dan pengendara kendaraan. Dokumentasi pemasangan rambu batas kecepatan maksimum kendaraan dengan nilai $40 \mathrm{~km} /$ jam ditunjukkan pada Gambar 8. Selain rambu batas kecepatan maksimum juga dipasang 2 (dua) buah rambu petunjuk penyeberangan jalan tepat di depan pintu masuk kampus Fakultas Teknik Unsoed Blater pada sisi kiri dan sisi kalan jalan. Dokumentasi pemasangan rambu lalu lintas petunjuk penyeberangan jalan ditunjukkan pada Gambar 9 dan Gambar 10. 


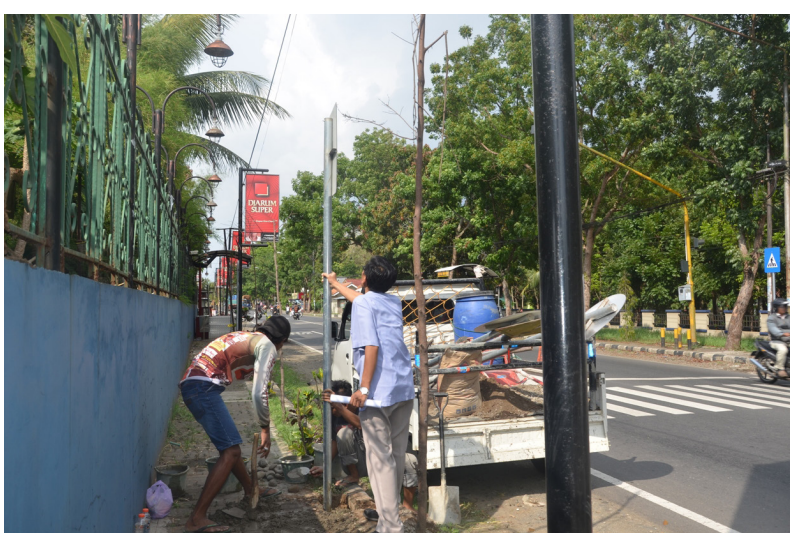

Gambar 9. Pemasangan rambu lalu lintas petunjuk penyeberangan jalan di sisi kiri jalan.

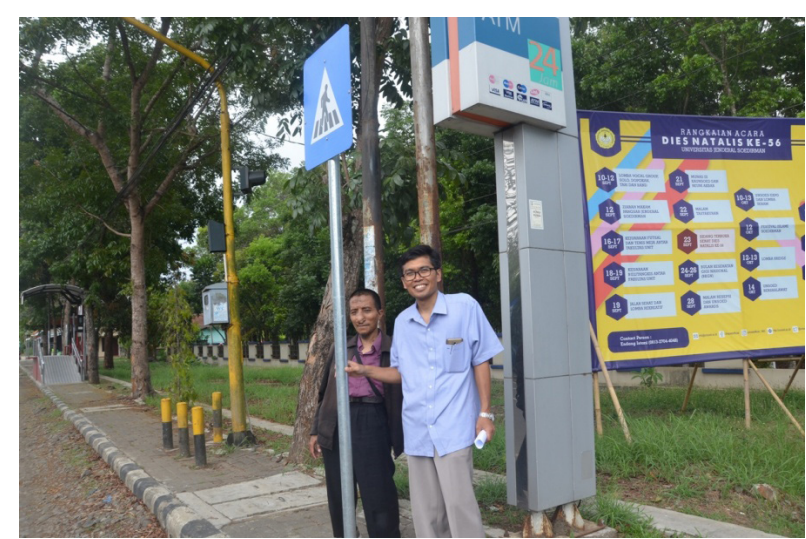

Gambar 10. Rambu petunjuk penyeberangan jalan di depan Kampus FT Unsoed Blater.

\section{SIMPULAN}

Upaya untuk menekan angka kecelakaan lalu lintas dapat dilakukan dengan mengimplementasikan hasil audit keselamatan jalan, mendesain jalan yang pemaaf yang mampu meminimalisir keparahan korban apabila tabrakan (forgiving road), jalan yang mampu menjelaskan maksud tanpa komunikasi (self-explaining road), dan jalan yang mampu menciptakan kepatuhan tanpa peringatan (selfregulating road). Hasil audit keselamatan jalan di ruas Jalan Mayjen Sungkono, Blater, Purbalingga yang harus diperbaiki yaitu aspek geometrik jalan berupa perbedaaan elevasi antara jalan dengan bahu jalan dan aspek harmonisasi fasilitas perlengkapan jalan. Penanganan yang sudah dilakukan yaitu dengan menentukan nilai batas kecepatan pada saat jam masuk/ pulang sekolah sebesar $30 \mathrm{~km} / \mathrm{jam}$, melakukan pengurugan bahu jalan sehaingga elevasinya sama dengan elevasi badan jalan dan memasang dua buah rambu batas kecepatan maksimum kendaraan $40 \mathrm{~km} / \mathrm{jam}$ dan dua buah rambu petunjuk penyeberangan jalan di kawasan Kampus Fakultas Teknik Universitas Jenderal Soedirman (UNSOED) Blater.

\section{UCAPAN TERIMA KASIH}

Penulis mengucapkan terima kasih kepada Direktorat Riset dan Pengabdian Masyarakat, Direktorat Jenderal Penguatan Riset dan Pengembangan, Kementerian Riset, Teknologi, dan Pendidikan Tinggi Republik Indonesia yang telah memberi dukungan finansial terhadap kegiatan pengabdian kepada masyarakat melalui skim Program Kemitraan Masyarakat (PKM) dengan Kontrak Nomor: 059/SP2H/PPM/ DRPM/2019 Tahun Anggaran 2019.

\section{DAFTAR PUSTAKA}

Direktorat Jenderal Bina Marga. (1997). Tata Cara Perencanaan Geometrik Jalan Antar Kota. Jakarta: Kementerian Pekerjaan Umum Republik Indonesia.

Direktorat Jenderal Perhubungan Darat. (2004). Cetak Biru Keselamatan Lalu Lintas dan Angkutan Jalan. Jakarta: Direktorat Lalu Lintas dan Angkutan Jalan, Direktorat Jenderal Perhubungan Darat, Kementerian Perhubungan Republik Indonesia.

Direktorat Jenderal Bina Marga. (2006). Kajian Kebutuhan Pelaksanaan Keselamatan Jalan di Indonesia. Jakarta: Kementerian Pekerjaan Umum Republik Indonesia.

Direktorat Keselamatan Transportasi Darat (DKTD). (2006). Manajemen Keselamatan Transportasi Jalan, Naskah Workshop Manajemen Keselamatan Transportasi Darat. Jakarta: Direktorat Jenderal Perhubungan Darat, Kementerian Perhubungan Republik Indonesia.

Fadli, A., Sugiyanto, G., \& Zulfa, M.I. (2020). Upaya Mereduksi Jumlah Kecelakaan Lalu Lintas Melalui Penggunaan Sistem Informasi Geografis. Warta LPM, 23(2), 115-128. https://doi.org/10.23917/ 
warta.v23i2.9895.

Global Road Safety Partnership. (2008). Speed Management: A Road Safety Manual for Decision-Makers and Practitioners. Geneva.

Gresnews. (2014). Indonesia urutan Kelima Negara dengan Kecelakaan tewas tertinggi. Gresnews (Koran), 26 Januari 2014. www.gresnews.com/berita/hukum/1530261-Indonesia-urutankelima-negaradengan-kecelakaan-tewas-tertinggi.

Hughes, B.P., Anund, A., \& Falkmer, T. (2015). System Theory and Safety Models in Swedish, UK, Dutch and Australian Road Safety Strategies. Accident Analysis and Prevention, 74, 271-278. Retrieved from https://doi.org/10.1016/j.aap.2014.07.017.

Indrastanti, S.R., Bayu, A.D., Nursiam, Sari, S.P. \& Mukharomah, W. (2010). Pendampingan Penyusunan Dokumen Rencana Pembangunan Jangka Menengah Desa. Warta LPM, 13(2), 120-127. https:// doi.org/10.23917/warta.v19i3.3228.

Kepolisian Resort Purbalingga. (2018). Data Kecelakaan di Kabupaten Purbalingga Tahun 2016-2017. Purbalingga: Polres Purbalingga (Unpublished).

Kementerian Perhubungan Republik Indonesia. (2014). Peraturan Menteri Perhubungan Republik Indonesia Nomor PM 13 Tahun 2014 tentang Rambu Lalu Lintas. Jakarta: Kementerian Perhubungan Republik Indonesia.

Kementerian Perhubungan Republik Indonesia. (2015). Peraturan Menteri Perhubungan Republik Indonesia No 111 Tahun 2015 tentang Tata Cara Penetapan Batas Kecepatan. Jakarta: Kementerian Perhubungan Republik Indonesia.

Kementerian Perhubungan Republik Indonesia. (2018). Peraturan Menteri Perhubungan Republik Indonesia Nomor PM 67 Tahun 2018 tentang Perubahan atas Peraturan Menteri Perhubungan Nomor PM 34 Tahun 2014 tentang Marka Jalan. Jakarta: Kementerian Perhubungan Republik Indonesia.

Kementerian Perhubungan Republik Indonesia. (2019). Statistik Perhubungan Buku I 2018. Jakarta: Pustikom Kementerian Perhubungan Republik Indonesia.

Khisty, C.J. \& Kent, B.L. (2003). Dasar-dasar Rekayasa Transportasi (Transportation Engineering: An Introduction). Jakarta: Erlangga.

Korps Lalu Lintas (Korlantas) Polri. (2019). Polantas dalam Angka 2018. Jakarta: Korlantas Kepolisian Negara Republik Indonesia.

Korps Lalu Lintas (Korlantas) Polri. (2019). Polantas dalam Angka: Grafik Kelompok Umur Korban. Jakarta: Korlantas Kepolisian Negara Republik Indonesia. http://korlantas.polri.go.id/korlantas/ statistik-2/.

Majid, A. \& Mehrzad, M. (2013). Geometric Design Consistency Model Based on Speed and Safety in Rural Highways in Some European Countries: A Review. International Journal of Structural and Civil Engineering Research.

Pratama, S.B. (2019). Penentuan Nilai Batas Kecepatan Maksimum Kendaraan di Kawasan Sekolah Kabupaten Purbalingga. (Unpublished Skripsi). Jurusan Teknik Sipil, Fakultas Teknik, Universitas Jenderal Soedirman Purwokerto.

Pusat Litbang Prasarana Transportasi. (2005). Penanganan Lokasi Rawan Kecelakaan Lalu Lintas: Pd.T09-2004-B. Jakarta: Departemen Permukiman dan Prasarana Wilayah, Kementerian Pekerjaan Umum Republik Indonesia.

Schepers, P., Hagenzieker, M., Methorst, R., Wee, B.V., \& Wegman, F. (2014). A conceptual framework for road safety and mobility applied to cycling safety. Accident Analysis and Prevention, 62, 331-340. http://dx.doi.org/10.1016/j.aap.2013.03.032.

Sendow, T. (2004). Analisa Jarak Pandangan di Lengkung Horisontal dan Lengkung Vertikal. (Unpublished Tesis). Program Magister Teknik Sipil, Institut Teknologi Bandung, Bandung. 
Sugiyanto, G. (2008). Biaya Kemacetan (Congestion Charging) Mobil Pribadi di Central Business District (Studi Kasus Kawasan Malioboro Jogjakarta). Media Teknik Sipil, 8(1), 59-66. http://media.sipil. ft.uns.ac.id/index.php/mts/article/view/63/63.

Sugiyanto, G., Malkhamah, S., Munawar, A., \& Sutomo, H. (2011). Estimation of Congestion Cost of Motorcycles Users in Malioboro, Yogyakarta, Indonesia. International Journal of Civil \& Environmental Engineering (IJCEE), 11(1), 56-63. http://citeseerx.ist.psu.edu/viewdoc/ download?doi=10.1.1.207.5872\&rep=rep1\&type=pdf.

Sugiyanto, G. \& Santi, M.Y. (2015). Karakteristik Kecelakaan Lalu Lintas dan Pendidikan Keselamatan Berlalulintas Sejak Usia Dini (Studi Kasus di Kabupaten Purbalingga). Semesta Teknika, 18(1), 65-75. http://journal.umy.ac.id/index.php/st/article/view/707.

Sugiyanto, G. (2016). The Impact of Congestion Pricing Scheme on The Generalized Cost and Speed of Motorcycle to The City of Yogyakarta, Indonesia. Journal of Engineering and Applied Sciences, 11(8), 1740-1746. http://medwelljournals.com/abstract/?doi=jeasci.2016.1740.1746.

Sugiyanto, G., Fadli, A., \& Santi, M.Y. (2017). Identification of Black Spot and Equivalent Accident Number Using Upper Control Limit Method. ARPN Journal of Engineering and Applied Sciences, 12(2), 528-535. http://www.arpnjournals.org/jeas/research_papers/rp_2017/jeas_0117_5650.pdf

Sugiyanto, G. (2017). Characterization of Asphalt Concrete Produced from Scrapped Tire Rubber. Engineering Journal, 21(4), 193-206. https://doi.org/10.4186/ej.2017.21.4.193.

Sugiyanto, G. (2017). The Cost of Traffic Accident and Equivalent Accident Number in Developing Countries (Case Study in Indonesia). ARPN Journal of Engineering and Applied Sciences, 12(2), 389-397. http://www.arpnjournals.org/jeas/research_papers/rp_2017/jeas_0117_5631.pdf.

Sugiyanto, G. \& Santi, M.Y. (2017). Road Traffic Accident Cost Using Human Capital Method (Case Study in Purbalingga, Central Java, Indonesia). Jurnal Teknologi (Sciences and Engineering), 79(2), 107116. https://doi.org/10.11113/jt.v79.5375.

Sugiyanto, G. (2018). The Effect of Congestion Pricing Scheme on The Generalized Cost and Speed of Motorcycle. Walailak Journal of Science and Technology (WJST), 15(1), 95-106. http://wjst.wu.ac. th/index.php/wjst/article/view/2347.

Sugiyanto, G. \& Malkhamah, S. (2018). Determining The Maximum Speed Limit in Urban Road to Increase Traffic Safety. Jurnal Teknologi (Sciences and Engineering), 80(5), 67-77. https://doi. org/10.11113/jt.v80.10489.

Sugiyanto, G., Jajang, \& Santi, M.Y. (2019a). The Impact of Lowering Speed Limit on Mobility and The Environment. The 1st International Conference on Material Science and Engineering for Sustainable Rural Development in AIP Conference Proceeding 2094(1) 020019, 1-8. https://doi. org/10.1063/1.5097488.

Sugiyanto, G., Fadli, A., Suciningtyas, R., Indriyati, E.W., \& Santi, M.Y. (2019b). Road Safety Audit at Black Spot Area (Case Study in Tlahab Lor, Karangreja, Purbalingga), The 1st International Conference on Material Science and Engineering for Sustainable Rural Development in AIP Conference Proceeding 2094(1) 020020. https://doi.org/10.1063/1.5097489.

The Institute for Health Metrics and Evaluation (IHME). (2018). Findings from the Global Burden of Disease Study 2017. http://www.healthdata.org/sites/default/files/files/policy_report /2019/ GBD_2017_Booklet.pdf.

Treat, J.R., Tumbas, N.S., McDonald, S.T., Shinar, D., Hume, R.D., \& Meyer, R.E. (1977). Tri-Level Study of the Causes of Traffic Accidents. Washington: NTHSA.

Wang, X., Yuan, J., Schultz, G.G., \& Fang, S. (2018). Investigating The Safety Impact of Roadway Network Features of Suburban Arterials in Shanghai. Accident Analysis and Prevention, 113, 137-148. https://doi.org/10.1016/j.aap.2018.01.029. 